\title{
Article \\ Effect of Zinc-Calcium on Xylose Consumption by Mucor circinelloides (MN128960): Xylitol and Ethanol Yield Optimization
}

\author{
Hector M. Fonseca-Peralta ${ }^{1}$, Karen V. Pineda-Hidalgo ${ }^{1}{ }^{\circledR}$, Claudia Castro-Martínez ${ }^{2}$ \\ and Ignacio Contreras-Andrade ${ }^{1, *(\mathbb{D}}$ \\ 1 Posgrado Regional de Biotecnología, Facultad de Ciencias Químico Biológicas, Universidad Autónoma de \\ Sinaloa, Culiacan 80030, Sinaloa, Mexico; h.fonseca.fcqb@uas.edu.mx (H.M.F.-P.); \\ kvpineda@uas.edu.mx (K.V.P.-H.) \\ 2 Centro Interdisciplinario de Investigación para el Desarrollo Integral Regional Unidad Sinaloa, Instituto \\ Politécnico Nacional (IPN, CIIDIR SINALOA), Guasave 81049, Sinaloa, Mexico; clcastro@ipn.mx \\ * Correspondence: ica@uas.edu.mx; Tel.: +52-(667)-713-78-60 (ext. 115)
}

\section{check for}

updates

Citation: Fonseca-Peralta, H.M.;

Pineda-Hidalgo, K.V.;

Castro-Martínez, C.;

Contreras-Andrade, I. Effect of

Zinc-Calcium on Xylose

Consumption by Mucor circinelloides

(MN128960): Xylitol and Ethanol

Yield Optimization. Energies 2022, 15,

906. https://doi.org/10.3390/

en15030906

Academic Editor: Tae Hyun Kim

Received: 17 November 2021

Accepted: 21 December 2021

Published: 27 January 2022

Publisher's Note: MDPI stays neutral with regard to jurisdictional claims in published maps and institutional affiliations.

Copyright: () 2022 by the authors. Licensee MDPI, Basel, Switzerland. This article is an open access article distributed under the terms and conditions of the Creative Commons Attribution (CC BY) license (https:// creativecommons.org/licenses/by/ $4.0 /)$.

\begin{abstract}
Xylose is the second most abundant monomeric sugar on earth. Nevertheless, metabolizing xylose into ethanol is a complex process due to several biochemical reactions. Some microorganisms of the genus Mucor are suitable for this bioprocess. Using metal ions, such as zinc and calcium, allows some fungal species to increase their ethanol yield. In this work, the wild strain Mucor spp. (C1502) was molecularly identified via internal transcribed spacer (ITS) sequencing. Secondly, an optimization using response surface methodology (RSM) with a central composite experimental design (CCD) was carried out. The independent variables (X) were $\mathrm{ZnSO}_{4} \cdot 7 \mathrm{H}_{2} \mathrm{O}(\mathrm{X} 1,0.0-1.5 \mathrm{~g} / \mathrm{L})$ and $\mathrm{CaCl}_{2}(\mathrm{X} 2,0.0-2.5 \mathrm{~g} / \mathrm{L})$ concentration in the fermentation broth in order to demonstrate the effect of these ions, xylose was used as the only carbon source. The dependent variables (Y) measured were ethanol yield (Y1, g ethanol/g xylose) and xylitol yield (Y2, g xylitol/g xylose). The identified strain, Mucor circinelloides, was given the accession number MN128960 by the NCBI. Once the optimal concentrations of zinc and calcium were calculated, experimental validation was performed, with the highest ethanol and xylitol yields reaching $0.36 \mathrm{~g}$ ethanol/g xylose and $0.35 \mathrm{~g}$ xylitol/g xylose, respectively. This study demonstrated that increasing the xylitol yield using the effect of the ions, zinc and calcium, increases the ethanol yield. Furthermore, M. circinelloides (C1502) can produce metabolites, such as ethanol and xylitol, from the xylose obtained from hemicellulose biomasses, which can be used as a carbon source at low cost and with great availability.
\end{abstract}

Keywords: xylose; Mucor circinelloides; fermentation; ethanol; xylitol; zinc; calcium; optimization; biofuels

\section{Introduction}

Biofuels, a renewable energy source, have gathered a significant amount of attention in the last decade [1]. Since carbon dioxide $\left(\mathrm{CO}_{2}\right)$ emissions have increased because of the use of fossil hydrocarbon fuels, biofuels have become an environmental alternative [2]. In this context, biomasses are a suitable feedstock for bioethanol production [3]. Usually, second-generation ( $2 \mathrm{G}$ ) biofuel production uses lignocellulose mainly from agricultural, forestry and municipal wastes, as well as from energy crops and pulp paper [4-9]. Biomass hydrolysis facilitates the production of fermenting sugars, such as glucose, the most abundant monomeric sugar in lignocellulose (30-50\%), and xylose, the second most abundant sugar (18-30\%) [10], for ethanol production and the production of other metabolites, such as xylitol and lipids [11,12]. However, xylose consumption is an arduous process given that there are few native microorganisms with the xylose pathway [13]. Currently, there are bioprocesses, such as consolidated bioprocessing (CBP) and simultaneous saccharification and co-fermentation (SSCF), that transform biomass feedstock directly into ethanol [14]. Due to the environmental impact and the overall production cost, CBP and SSCF are the most promising bioprocesses. They usually involve a single microorganism for enzyme 
production and fermentation [15], but sometimes more than one microorganism can also be used [16,17]. It is not enough for a microorganism to be able to utilize xylose, for they must also have hydrolytic enzymes. There are few microorganisms with the "whole genespackage" that are able to carry out these multiple bioreactions. Some authors consider the fungi of the genera Trametes, Flammulina, Fusarium, and Mucor to be CBP-performing microorganisms for bioethanol production [18-21]. Advantageously, Mucor circinelloides produces ethanol under aerobic conditions [22]. Moreover, since it is an oleaginous fungus, it can be used as a third-generation biomass for biodiesel production [13]. In the taxonomy classification, Mucor circinelloides is a member of the Zygomycota division, Zygomycetes class, Mucorales order, and Mucoraceae family [23]. In this respect, Mucor circinelloides is a profitable wild strain due to its ability to carry out all the reactions involved in a CBP [12,24-26]. However, even if hexoses fermentation, such as with glucose and fructose, is successful and efficient, xylose fermentation continues to be one of the biggest challenges for these bioprocesses. Metabolizing xylose into ethanol is such a complex process due to several biochemical reactions.

There are two pathways for xylose metabolism in microorganisms: the xylose isomerase pathway and the xylose oxidoreductive pathway [27]. The xylose isomerase pathway, commonly found in prokaryotes, transforms D-xylose into D-xylulose via xylose isomerase (XI) [13]. On the other hand, the xylose oxidoreductive pathway, mainly found in yeasts and fungi, such as Mucor circinelloides, reduce the D-xylose to xylitol via xylose reductase (XR) and, subsequently, xylitol is transformed into D-xylulose via xylitol dehydrogenases $(\mathrm{XDH})$ and then is incorporated into the pentose phosphate pathway (PPP) [28]. $M$. circinelloides contains three genes that encode $\mathrm{XI}, \mathrm{XDH}$, and $\mathrm{XK}$, which indicates that the xylose isomerase pathway and the xylose oxidoreductive pathway simultaneously exist in $M$. circinelloides [29]. Given what we know from the literature, that $M$. circinelloides has the xylose metabolism pathway is very comprehensible. There are different strategies in the literature that are focused on increasing xylose consumption and regulating metabolisms for ethanol production. One of these is the enzymatic overexpression brought on by metabolic engineering $[13,19]$. The other that is widely explored is the use of micronutrients or metal ions, which have an essential role in metabolism regulation mechanisms, such as catalytic induction, because they act like enzymatic cofactors [30]. For instance, zinc participates in the catalytic site in XDH and XK [27]. Additionally, it is one of the essential micronutrients in fungi. It is related to many biological processes, such as transcriptional regulation, the metabolism of sugars and amino acids, enzymatic activity, antioxidant effects, and homeostasis [31,32]. Moreover, Cuero et al. (2015) reported that zinc increases alcohol dehydrogenase (ADH) expression in some fungi, including F. gramineum and Aspergillus niger [33]. Additionally, zinc has been used to increase ethanol yield in Saccharomyces cerevisiae and Mucor indicus [12,34]. Another metal ion of importance in fungi is calcium. It plays several roles in the transduction of cellular signals and cell growth under stress conditions [35]. Furthermore, one study revealed that calcium activates the calcineurin, which plays a crucial role during the yeast-hyphal growth transition of $M$. circinelloides [36]. Since calcium is involved in morphological regulation, and the yeast phase is associated with high rates of ethanol production under anaerobiosis, an effect can be denied [37]. Further interactions and behaviors among media components in the fermentation optimization process can be understood using a powerful and efficient mathematical approach, such as RSM. In this present study, we evaluated the effect of zinc and calcium on the xylose consumption of the wild strain Mucor spp. (C1502) through an RSM analysis, using a CCD optimization to measure xylitol and ethanol yield.

\section{Materials and Methods}

\subsection{Microorganism Identification}

The fermentations were performed using Mucor spp. C1502, a wild strain isolated from a Ganoderma carpophore in Sinaloa, Mexico. The strain's identity was based on morphological analyses. A microscopic observation of the isolated microorganisms was carried 
out with methylene blue staining. The strain identities were confirmed by sequencing the ITS using the primers ITS4 and ITS1. Fungal genomic DNA was extracted using DNAzol (DNAzol $^{\circledR}$, Invitrogen Cat. No. 10503027, Cincinnati, OH, USA), following the manufacturer's recommendations. Genomic DNA was suspended in $30 \mu \mathrm{L}$ of ultrapure water. For the DNA amplification of the complete internal transcribed sequences (ITS) of the rDNA region (its1-5.8SrDNA-its2), the primer sets ITS-1 (5'-TCCGTAGGTGAACCTGCGG-3') and ITS4 (5'-TCCTCCGCTTATTGATATGC-3') were used [38]. PCR analysis was conducted in a reaction volume of $25.0 \mu \mathrm{L}$ that included: $17.65 \mu \mathrm{L}$ of ultrapure water, $2.5 \mu \mathrm{L}$ of buffer, $0.75 \mu \mathrm{L}$ of $50 \mu \mathrm{M} \mathrm{MgCl}_{2}, 1.0 \mu \mathrm{L}$ of each primer $(10 \mu \mathrm{M}), 1 \mu \mathrm{L} 10 \mathrm{mM}$ dNTP mix, $0.1 \mu \mathrm{L}$ (1 U) of Taq platinum DNA polymerase (Invitrogen, USA), and $1.0 \mu \mathrm{L}$ of template DNA (10 ng). The PCR was performed using the following conditions: an initial denaturing step was conducted at $94{ }^{\circ} \mathrm{C}$ for $5 \mathrm{~min}$; subsequently, 30 cycles consisting of $30 \mathrm{~s}$ at $94{ }^{\circ} \mathrm{C}$ were followed by $30 \mathrm{~s}$ at $60{ }^{\circ} \mathrm{C}$ for annealing and $30 \mathrm{~s}$ at $72{ }^{\circ} \mathrm{C}$ for extension; and a final extension step of $5 \mathrm{~min}$ was conducted at $72{ }^{\circ} \mathrm{C}$. The PCR products were purified using the QIAquick PCR purification Kit (Qiagen ${ }^{\circledR}$, Cat. No. 28106. Germantown, MD, USA) and sequenced bi-directionally. DNA sequencing was performed using the Sanger method, (1979), in the sequencing unit of LANGEBIO, CINVESTAV (Irapuato, Mexico). DNA alignments were compared in the GenBank database using the BLAST-N software and the Mega-Blast algorithm (NCBI-National Center for Biotechnology Information).

\subsection{Fermentation}

The inoculum broth contained $(\mathrm{g} / \mathrm{L})$ : 50 glucose, 5 yeast extract, $3.5 \mathrm{KH}_{2} \mathrm{PO}_{4}$ $7.5\left(\mathrm{NH}_{4}\right)_{2} \mathrm{SO}_{4}, 0.75 \mathrm{MgSO}_{4} \cdot 7 \mathrm{H}_{2} \mathrm{O}$ [15]. Three $1 \mathrm{~cm}^{2}$ fungal mycelium squares were added to the inoculum broth. Then, the broth was incubated at $28{ }^{\circ} \mathrm{C}$ and $150 \mathrm{rpm}$ for $48 \mathrm{~h}$ (glucose $=0 \mathrm{~g} / \mathrm{L})$. The fermentation broth contained $(\mathrm{g} / \mathrm{L}): 50$ xylose, 7.5 yeast extract, $3.5 \mathrm{KH}_{2} \mathrm{PO}_{4}, 7.5\left(\mathrm{NH}_{4}\right)_{2} \mathrm{SO} 4,0.75 \mathrm{MgSO}_{4} \cdot 7 \mathrm{H}_{2} \mathrm{O}$ [24]. The experiments were carried out in $50 \mathrm{~mL}$ flasks and the total volume was $30 \mathrm{~mL}$. The flasks were inoculated with the $10 \%$ M. circinelloides inoculum. Then they were incubated at $28^{\circ} \mathrm{C}$ and $150 \mathrm{rpm}$ for $144 \mathrm{~h}$ (xyose $=0 \mathrm{~g} / \mathrm{L}$ ). A sample of $2 \mathrm{~mL}$ was taken every $12 \mathrm{~h}$ during the fermentation.

\subsection{Optimization and Statistical Analysis}

The experimental design was performed according to RSM using Design-Expert 10.0.01 (Stat-Ease, Minneapolis, MN, USA) trial version software [39]. CCD was employed to study the effect of two independent variables $(X)[40,41]$, which were the $\mathrm{ZnSO}_{4} \cdot 7 \mathrm{H}_{2} \mathrm{O}$ $(\mathrm{X} 1,0.0-1.5 \mathrm{~g} / \mathrm{L})$ and $\mathrm{CaCl}_{2}(\mathrm{X} 2,0.0-2.5 \mathrm{~g} / \mathrm{L})$ concentration in the fermentation broth. The dependent variables $(\mathrm{Y})$ measured were the ethanol yield (Y1, g ethanol/g xylose) and the xylitol yield (Y2, g xylitol/g xylose). The yields were obtained from the average of the triplicate for each experiment, and were measured with regard to the concentration of ethanol and xylitol (g/L). Once the data were filled, the model was chosen for each independent variable according to the software suggestion. Then, the analysis of variance (ANOVA) was performed in the same software to verify if the model was significant according to the statistical criteria determined by Fisher's F-test and values of probability $p>F$. Applying the stepwise regression procedure, non-significant terms $(p>0.1)$ were deleted from a second order polynomial and a new polynomial was used to obtain a predictive model for each response variable. The numeric desirability method of the RSM allowed us to visualize the maximum ethanol yield at the best combination. Due to the fact that xylitol is a metabolite that feeds the ethanol pathway, increasing the yield is considered to be the best option. The fitted model for the dependent variables was evaluated at any point $X=(X 1, X 2)$ of the experimental zone, where the model predicted a response variable value, $Y 1(X)$ and $Y 2(X)$. Then, Yi $(X)$ was transformed into a value di $(X)$, which fell in the range $(0,1)$ and measured the desirability of the response to which the optimum value intended to reach. In this case, the highest ethanol yield value is obtained. Then, the optimum value of desirability (D) is $\mathrm{D}=1$; however, an acceptable estimation for $\mathrm{D}$ can be between 0.6 and 0.9 . 


\subsection{Analytical Assays}

Ethanol, xylitol, glucose, and xylose concentrations were measured in an UHPLC (Ultra-High-Pressure Liquid Chromatography) Acquity Arc equipment (WATERS, Milford, MA, USA). Samples were eluted with $0.005 \mathrm{M} \mathrm{H}_{2} \mathrm{SO}_{4}$ and a flow rate of $0.6 \mathrm{~mL} / \mathrm{min}$ using an Aminex HPX-87H ion exclusion organic acid analysis column $(300 \times 7.8 \mathrm{~mm})(\mathrm{BIO}-\mathrm{RAD}$, Hercules, CA, USA).

\section{Results}

\subsection{Microorganism Identification}

The morphological and phylogenetic analyses confirmed the strain identity as Mucor circinelloides. In Figure 1, the morphological characteristics of the strain are presented. The macroscopic characterization shows gray and aerial mycelium (a), while the microscopic characteristics are sporangiospores (biggest globes), showed in (b) [42]. The hyphal-yeast morphology can be observed in (c) and (d), where the yeast shape appeared as globes with agglomerations adhered in the hypha [43].

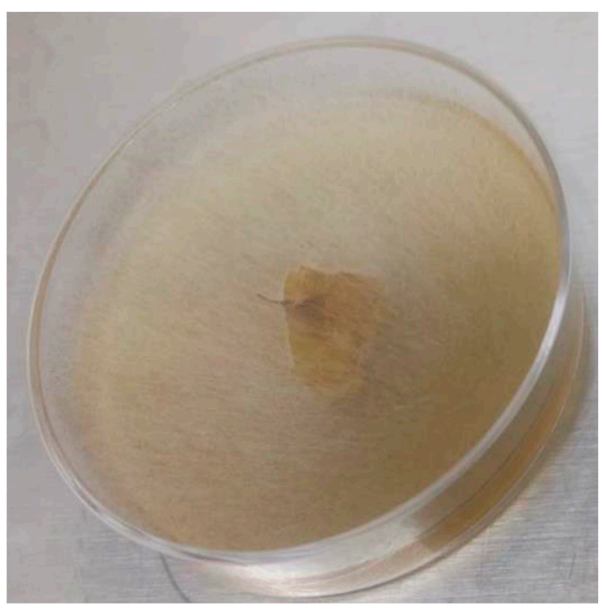

(a)

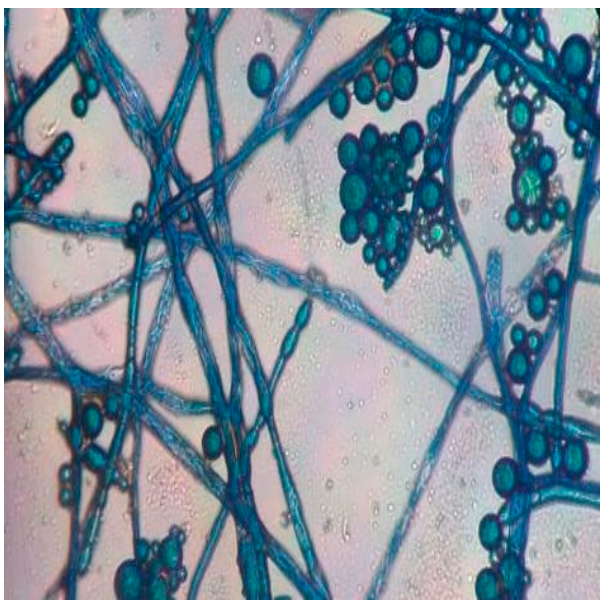

(c)

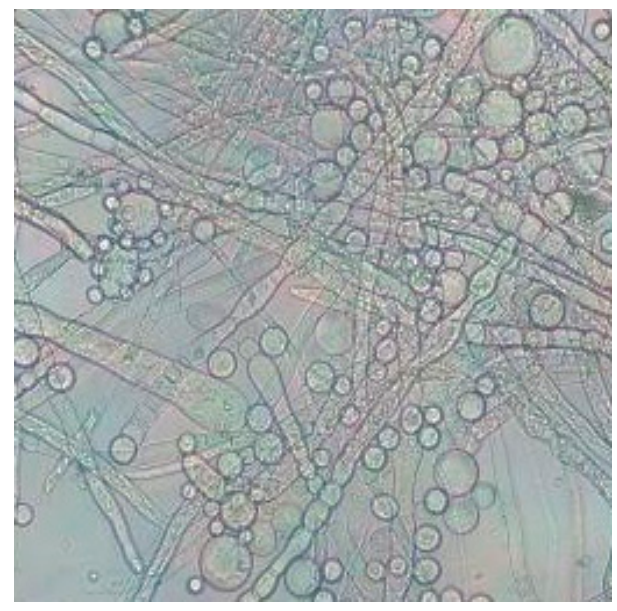

(b)

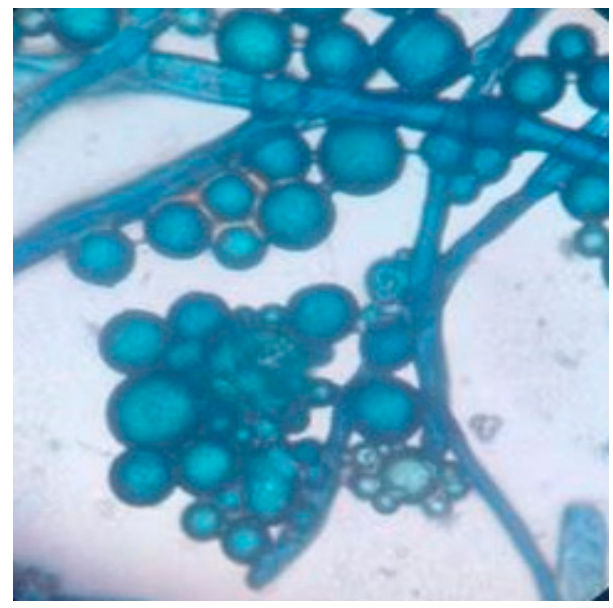

(d)

Figure 1. Morphological characteristic of M. circinelloides (C1502). (a) Macroscopic characteristics, (b) microscopic characteristics at 40×, (c,d) lactophenol cotton blue-dyed samples at $40 \times$ and $100 \times$, respectively.

The obtained sequence from the strain C1502 with a length of 514 base pairs (pb) contained the complete ITS1-5.8S-rDNA and the partial ITS2. After the sequence submission, the accession number MN128960 was provided by GenBank. BLAST-N homology analysis 
between the sequence from the amplified rDNA region of the strain $\mathrm{C} 1502$ and the Mucor circinelloides AF412286.1 strain showed that they share $100 \%$ of their identity.

\subsection{Prediction Models for RSM}

Fermentations were carried out according to the following experimental design using the strain Mucor circinelloides C1502 (MN128960) (Table 1). The ethanol yields in the experiments ranged from 0.081 to $0.197 \mathrm{~g}$ ethanol $/ \mathrm{g}$ xylose. These yields were the highest ethanol concentrations $(\mathrm{g} / \mathrm{L})$ obtained at $84 \mathrm{~h}$ of fermentation. The values of the xylitol yields were from 0.175 to $0.244 \mathrm{~g}$ xylitol/g xylose. These yields were the highest concentrations obtained at $60 \mathrm{~h}$ of fermentation and this was due to the fact that xylitol production occurred before ethanol.

Table 1. Experimental design ${ }^{1}$ used to obtain the maximum ethanol yield $(\mathrm{g} / \mathrm{g})$.

\begin{tabular}{|c|c|c|c|c|}
\hline \multirow{2}{*}{ Assay $^{2}$} & \multicolumn{2}{|c|}{ Process Variables (g/L) } & \multicolumn{2}{|c|}{ Response Variables (g/g) } \\
\hline & $\mathrm{ZnSO}_{4} \cdot 7 \mathrm{H}_{2} \mathrm{O}$ & $\mathrm{CaCl}_{2}$ & Ethanol Yield $^{3}$ & Xylitol Yield $^{4}$ \\
\hline 1 & 0.220 & 0.366 & 0.208 & 0.159 \\
\hline 2 & 1.280 & 0.366 & 0.175 & 0.197 \\
\hline 3 & 0.220 & 2.134 & 0.217 & 0.114 \\
\hline 4 & 1.280 & 2.134 & 0.204 & 0.139 \\
\hline 5 & 0 & 1.250 & 0.223 & 0.146 \\
\hline 6 & 1.500 & 1.250 & 0.217 & 0.147 \\
\hline 7 & 0.750 & 0 & 0.178 & 0.196 \\
\hline 8 & 0.750 & 2.500 & 0.211 & 0.114 \\
\hline 9 & 0.750 & 1.250 & 0.200 & 0.120 \\
\hline 10 & 0.750 & 1.250 & 0.244 & 0.160 \\
\hline 11 & 0.750 & 1.250 & 0.225 & 0.139 \\
\hline 12 & 0.750 & 1.250 & 0.207 & 0.136 \\
\hline 13 & 0.750 & 1.250 & 0.242 & 0.162 \\
\hline
\end{tabular}

${ }^{1}$ Central composite rotatable design with two factors and five levels; 13 assays. ${ }^{2}$ Does not correspond to the order of processing. ${ }^{3}$ Ethanol yield (g ethanol/g xylose) at $84 \mathrm{~h} .{ }^{4}$ Xylitol yield (g xylitol/g xylose) at $60 \mathrm{~h}$.

\subsubsection{Ethanol Yield}

The effect of each factor and its interactions were analyzed using an analysis of variance (ANOVA). For ethanol yield, the ANOVA showed a significant quadratic model $(p<0.0342)$. This analysis shows that ethanol yield depends on the linear terms of $\left[\mathrm{ZnSO}_{4} \cdot 7 \mathrm{H}_{2} \mathrm{O}\right.$ concentration] $(p<0.2350)$ [ $\mathrm{CaCl}_{2}$ concentration] $(p<0.0743)$, as well as the quadratic term $\left[\mathrm{CaCl}_{2} \text { concentration }\right]^{2}(p<0.0208)$. Therefore, the prediction models for the maximum ethanol yield were:

Coded factors:

$$
\mathrm{Y}=0.22-6.707 \times 10^{-0.03} \times(\mathrm{X} 1)+0.011 \times(\mathrm{X} 2)-0.016(\mathrm{X} 2)^{2}
$$

Actual factors:

$$
\begin{aligned}
& \mathrm{Y}=0.18424-0.012646\left[\mathrm{ZnSO}_{4} \cdot 7 \mathrm{H}_{2} \mathrm{O} \text { concentration }\right]+0.062196\left[\mathrm{CaCl}_{2} \text { concentration }\right] \\
& -0.020065\left[\mathrm{CaCl}_{2} \text { concentration }\right]^{2} .
\end{aligned}
$$

The regression model $\left(R^{2}=0.6004\right)$ explains $60 \%$ of the variance, while the adjusted determination coefficient $R^{2}$ in the model was 0.4672 . The low difference between $R^{2}$ and the adjusted $R^{2}$ means that the model is well adjusted to the data. The lack of adjustment was non-significant $(p=0.9352)$, which is good because it allows the model to fit.

\subsubsection{Xylitol Yield}

For the xylitol yield, the ANOVA showed a significant linear model $(p<0.0210)$. This analysis demonstrated that the xylitol yield depended on the linear terms of $\left[\mathrm{ZnSO}_{4} \cdot 7 \mathrm{H}_{2} \mathrm{O}\right.$ 
concentration] $(p<0.3531)$ and $\left[\mathrm{CaCl}_{2}\right.$ concentration] $(p<0.0084)$. The prediction models for the maximum ethanol yield were:

Coded factors:

$$
\mathrm{Y}=0.16+8.157 \times 10^{-0.03} \times(\mathrm{X} 1)-0.027 \times(\mathrm{X} 2)
$$

Actual factors:

$\mathrm{Y}=0.17249+0.015381\left[\mathrm{ZnSO}_{4} \cdot 7 \mathrm{H}_{2} \mathrm{O}\right.$ concentration $]-0.031004\left[\mathrm{CaCl}_{2}\right.$ concentration $]$

The regression model $\left(R^{2}=0.7616\right)$ explains $76 \%$ of the variance, while the adjusted determination coefficient $R^{2}$ in the model was 0.7139 . The $R^{2}$ is a reasonable agreement with the adjusted $R^{2}$, and it means that the model is well adjusted to the data. The lack of adjustment was non-significant ( $p=0.8283$ ), which is good because it allows the model to fit.

\subsection{Ethanol and Xylitol Yield Optimization}

The model thus developed allowed us to continue with the numerical optimization. As a strategy to increase the ethanol yield at maximum value, different criteria for optimization were performed and we selected the best. This process consists of maximizing the xylitol yield and maintaining the ethanol yield in range. Figure 2a shows the global desirability $(\mathrm{D}=0.941)$ for the function of the $\mathrm{ZnSO}_{4} \cdot 7 \mathrm{H}_{2} \mathrm{O}$ and $\mathrm{CaCl}_{2}$ concentrations. The red-orange zone on the graphics indicates the optimal zone for each variable, while the intermedium and lower values are represented in the orange and green-blue zone, respectively. The optimal suggested concentrations were: $\mathrm{X} 1, \mathrm{ZnSO}_{4} \cdot 7 \mathrm{H}_{2} \mathrm{O}=1.5 \mathrm{~g} / \mathrm{L}$ and $\mathrm{X} 2, \mathrm{CaCl}_{2}=0.168 \mathrm{~g} / \mathrm{L}$ (Table 2). In Figure 2b, the 3D graph shows the effect over the ethanol yield of both ions. The optimal region is in the red-orange zone where calcium is above 1.5 to $2.0 \mathrm{~g} / \mathrm{L}$ and zinc concentration is around 0 to $0.5 \mathrm{~g} / \mathrm{L}$. However, Figure $2 \mathrm{c}$ shows that higher zinc concentration increases the xylitol yield, and less than $1 \mathrm{~g} / \mathrm{L}$ calcium is required.

Table 2. Comparison of model prediction and experimental values after the optimization.

\begin{tabular}{ccccccc}
\hline \multicolumn{2}{c}{$\begin{array}{c}\text { Concentration } \\
\text { Suggested (g/L) }\end{array}$} & \multicolumn{2}{c}{ Optimal Prediction (g/g) } & Desirability & \multicolumn{2}{c}{ Optimal Response } \\
$(\mathbf{g} / \mathbf{g})$
\end{tabular}

${ }^{1}$ Ethanol yield (g ethanol/g xylose) at $84 \mathrm{~h} .{ }^{2}$ Xylitol yield (g xylitol/g xylose) at $60 \mathrm{~h}$.

\subsection{Validation}

The experimental results of the fermentation performed at the suggested $\mathrm{ZnSO}_{4} \cdot 7 \mathrm{H}_{2} \mathrm{O}$ and $\mathrm{CaCl}_{2}$ concentrations are in Table 2. The optimal value for the ethanol yield was 0.34 (g ethanol/g xylose) against the control of 0.27 , which represented a non-optimized fermentation. Moreover, xylitol increased with respect to the control. It means that increasing xylitol production has a consequence for ethanol production. In addition, every $12 \mathrm{~h}$ during fermentation at optimal conditions, the yield was calculated. The ethanol yield was better at $48 \mathrm{~h}$ with 0.36 (g ethanol/g xylose) than at $84 \mathrm{~h}$. It means that the fermentation time could also be reduced through optimization. 


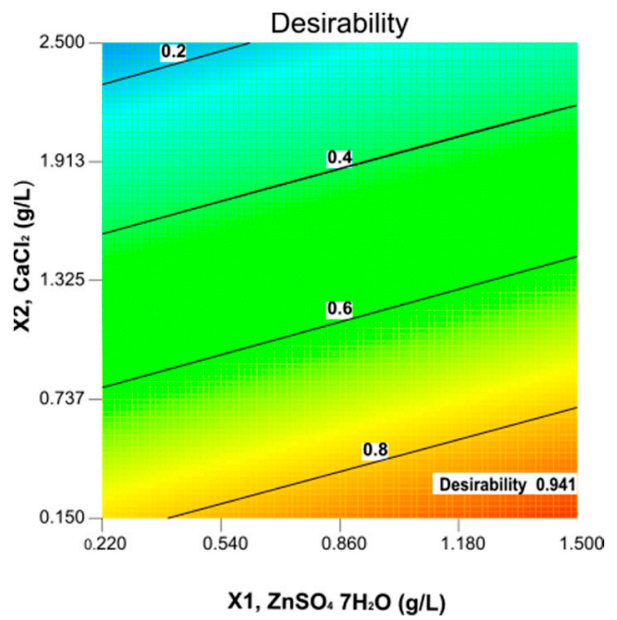

(a)

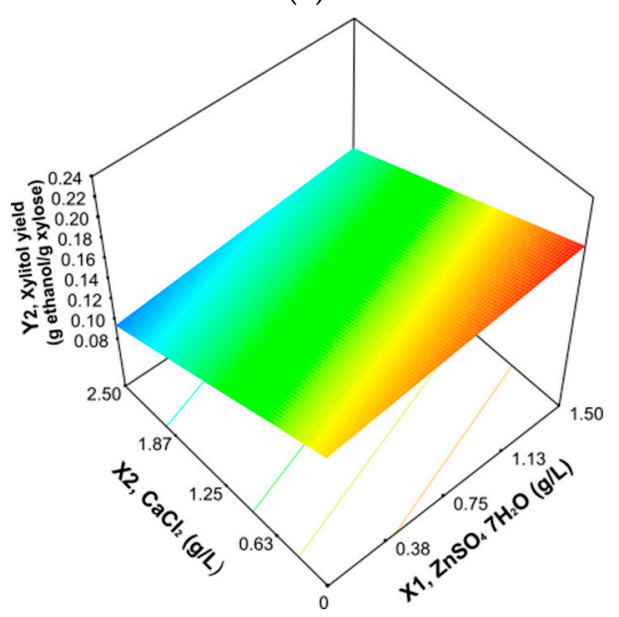

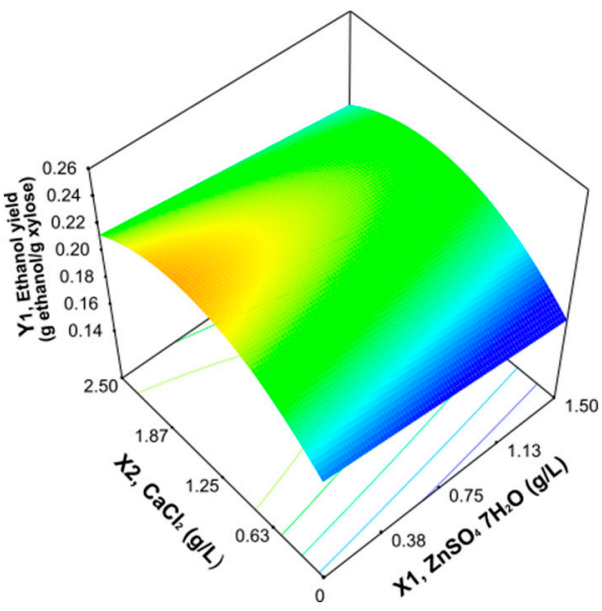

(b)

(c)

Figure 2. (a) Desirability plot showing the best combination of $\mathrm{ZnSO}_{4} \cdot 7 \mathrm{H}_{2} \mathrm{O}$ and $\mathrm{CaCl}_{2}$ for an optimal ethanol yield. (b) Response surface plots showing the effect of zinc and calcium on ethanol yield. (c) Response surface plots showing the effect of zinc and calcium on xylitol yield.

\section{Discussion}

Zygomycetes are very likely to produce organic acids [44]. Nevertheless, under the right conditions, strains such as Mucor circinelloides (C1502) are able to produce ethanol with xylose as a carbon source. Media composition optimization facilitates the enhancement of the yields from this bioprocess. Further speculations can be made when optimal behaviors are obtained. There are two phenomena presented during this optimization, according to our knowledge. The first is related to the effect of calcium and zinc ions on ethanol yield. Calcium, at a certain concentration, increases the ethanol yield, and zinc apparently decreases this dependent variable (Figure 1b). Calcium by itself can exhibit different mechanisms at the cell level, such as ion transport and morphological changes in fungi $[35,36]$. On the other hand, zinc by itself can cause membrane oxidation through its accumulation at higher concentrations and, as a result, the cell becomes stressed [31]. However, the second phenomenon regards the effect on xylitol yield. Zinc raises the xylitol yield, and calcium is necessary, too (Figure 1c). Apparently, there is a relationship between zinc accumulation and the effect of calcium on Mucor species [45]. In addition, zinc transportation in the cell is related to an unknown effect of calcium. Hypothetically, zinc is transported into the cell when the calcium concentration is optimal. Therefore, it could play several roles as an enzymatic cofactor, a transcription factor, and in homeostasis [32]. Moreno et al. (2020) reported that using clones of Candida intermedia resulted in ethanol and xylitol yields of 
about $0.22-0.33 \mathrm{~g}$ ethanol $/ \mathrm{g}$ xylose and $0.00-0.29 \mathrm{~g}$ xylitol/g xylose at $72 \mathrm{~h}$ of fermentation [46]. Takano et al. (2012), reported a similar ethanol yield of $0.34 \mathrm{~g}$ ethanol/g xylose at $96 \mathrm{~h}$ of fermentation, using the fungi Mucor circinelloides NBRC 4572 and the same culture medium conditions. Nevertheless, $1 \mathrm{~g}$ of $\mathrm{CaCl}_{2} \cdot 2 \mathrm{H}_{2} \mathrm{O}$ was added [21]. Even these results are very similar to our optimized results. We noticed, as an achievement, that the maximum yield obtained during fermentation was 0.36 (g ethanol/g xylose) at $48 \mathrm{~h}$, which is half the time of fermentation from other studies, which means that productivity is doubled using our method. That is why RSM has become in a useful tool that allows researchers to explore notorious effects in the bioprocess with a limited experimental design [47]. Effects can be on the catalytic activity of the enzymes related to xylose fermentation. Further molecular analyses are required to acknowledge the cellular effect of these ions during optimization. Other techniques, such as proteomics and metabolomics, may help to identify specifical bottlenecks in the metabolism process. There are many strategies that we need to develop before we upgrade to a pilot scale, however. Nevertheless, this study shows that maximizing the xylitol yield increases the ethanol yield. Furthermore, it is relevant to notice that in the biorefinery concept of lignocellulose, xylitol could be used as a high value metabolite [48].

\section{Conclusions}

In this work, it was possible to identify the strain as Mucor circinelloides (MN128960) through the ITS sequencing, which has a great potential to produce bioethanol and xylitol with xylose as a carbon source. In addition, RSM, performed to optimize $\mathrm{ZnSO}_{4} \cdot 7 \mathrm{H}_{2} \mathrm{O}$ and $\mathrm{CaCl}_{2}$ concentrations, was very useful for determining optimal values, which were $1.5 \mathrm{~g} / \mathrm{L}$ and $0.168 \mathrm{~g} / \mathrm{L}$, respectively. The ethanol yield at the optimized conditions was $0.34 \mathrm{~g}$ ethanol $/ \mathrm{g}$ xylose at $84 \mathrm{~h}$ of fermentation. The highest xylitol yield was $0.35 \mathrm{~g}$ xylitol/g xylose at $60 \mathrm{~h}$ fermentation and under optimal zinc and calcium conditions. Furthermore, it was demonstrated by this study that increasing the xylitol yield with $\mathrm{ZnSO}_{4} \cdot 7 \mathrm{H}_{2} \mathrm{O}$ and $\mathrm{CaCl}_{2}$ enhances the ethanol yield. Xylose fermentation for ethanol production is still performed on a laboratory scale. Another important topic is the time of fermentation. According to the data, fermentation can be carried out in $48 \mathrm{~h}$ rather than $84 \mathrm{~h}$. Since time can be reduced, the overall cost of production in a pilot or an industrial scale should decrease in several aspects.

Author Contributions: Conceptualization, I.C.-A.; methodology, H.M.F.P., K.V.P.-H. and C.C.-M.; software, H.M.F.-P.; validation, H.M.F.-P.; formal analysis, H.M.F.-P., K.V.P.-H. and C.C.-M.; investigation, H.M.F.-P., and I.C.-A.; resources, I.C.-A., writing - original draft preparation, H.M.F.-P.; writingreview and editing, I.C.-A.; visualization, C.C.-M. and K.V.P.-H.; supervision, I.C.-A.; project administration, I.C.-A., C.C.-M. and K.V.P.-H.; funding acquisition, C.C.-M. and I.C.-A. All authors have read and agreed to the published version of the manuscript.

Funding: Consejo Nacional de Ciencia y Tecnología: 175519, Universidad Autonoma de Sinaloa.

Institutional Review Board Statement: Not applicable.

Informed Consent Statement: Not applicable.

Data Availability Statement: Original data results can be found in the Biofuel Laboratory of the Universidad Autónoma de Sinaloa.

Acknowledgments: The authors extend their thanks to CONACYT for the scholarship awarded, and acknowledge the IPN, CIIDIR SINALOA for allowing the use of their facilities and for the financial support.

Conflicts of Interest: The authors declare no conflict of interest.

\section{References}

1. Ellabban, O.; Abu-Rub, H.; Blaabjerg, F. Renewable energy resources: Current status, future prospects and their enabling technology. Renew. Sustain. Energy Rev. 2014, 39, 748-764. [CrossRef]

2. Demirbas, A. Political, economic and environmental impacts of biofuels: A review. Appl. Energy 2009, 86, S108-S117. [CrossRef] 
3. Limayem, A.; Ricke, S.C. Lignocellulosic biomass for bioethanol production: Current perspectives, potential issues and future prospects. Prog. Energy Combust. Sci. 2012, 38, 449-467. [CrossRef]

4. Murphy, J.D.; McCarthy, K. Ethanol production from energy crops and wastes for use as a transport fuel in Ireland. Appl. Energy 2005, 82, 148-166. [CrossRef]

5. Guo, G.-L.; Chen, W.-H.; Chen, W.-H.; Men, L.-C.H.; Wang, W.-S. Characterization of dilute acid pretreatment of silvergrass for ethanol production. Bioresour. Technol. 2008, 99, 6046-6053. [CrossRef]

6. Soto-León, S.; López-Camacho, E.; Milán-Carrillo, J.; Sánchez-Castillo, M.A.; Cuevas-Rodríguez, E.; Picos-Corrales, L.A.; Contreras-Andrade, I. Jatropha cinerea seed oil as a potential non-conventional feedstock for biodiesel produced by an ultrasonic process. Revista Mexicana Ingeniería Química 2014, 13, 739-747.

7. Anwar, Z.; Gulfraz, M.; Irshad, M. Agro-industrial lignocellulosic biomass a key to unlock the future bio-energy: A brief review. J. Radiat. Res. Appl. Sci. 2014, 7, 163-173. [CrossRef]

8. Barros-Rios, J.; Romaní, A.; Garrote, G.; Ordas, B. Biomass, sugar, and bioethanol potential of sweet corn. GCB Bioenergy 2015, 7, 153-160. [CrossRef]

9. Ingale, S.; Joshi, S.J.; Gupte, A. Production of bioethanol using agricultural waste: Banana pseudo stem. Braz. J. Microbiol. 2014, 45, 885-892. [CrossRef]

10. Jørgensen, H.; Kristensen, J.B.; Felby, C. Enzymatic conversion of lignocellulose into fermentable sugars: Challenges and opportunities. Biofuels Bioprod. Biorefining 2007, 1, 119-134. [CrossRef]

11. Guo, Z.-P.; Robin, J.; Duquesne, S.; O’Donohue, M.J.; Marty, A.; Bordes, F. Developing cellulolytic Yarrowia lipolytica as a platform for the production of valuable products in consolidated bioprocessing of cellulose. Biotechnol. Biofuels 2018, 11, 141. [CrossRef] [PubMed]

12. Sues, A.; Millati, R.; Edebo, L.; Taherzadeh, M.J. Ethanol production from hexoses, pentoses, and dilute-acid hydrolyzate by Mucor indicus. FEMS Yeast Res. 2005, 5, 669-676. [CrossRef] [PubMed]

13. Zan, X.; Sun, J.; Chu, L.; Cui, F.; Huo, S.; Song, Y.; Koffas, M.A. Improved glucose and xylose co-utilization by overexpression of xylose isomerase and/or xylulokinase genes in oleaginous fungus Mucor circinelloides. Appl. Microbiol. Biotechnol. 2021, 105, 5565-5575. [CrossRef]

14. den Haan, R.; van Rensburg, E.; Rose, S.H.; Görgens, J.F.; van Zyl, W.H. Progress and challenges in the engineering of noncellulolytic microorganisms for consolidated bioprocessing. Curr. Opin. Biotechnol. 2015, 33, 32-38. [CrossRef] [PubMed]

15. Amore, A.; Faraco, V. Potential of fungi as category I Consolidated BioProcessing organisms for cellulosic ethanol production. Renew. Sustain. Energy Rev. 2012, 16, 3286-3301. [CrossRef]

16. Scully, S.M.; Orlygsson, J. Recent Advances in Second Generation Ethanol Production by Thermophilic Bacteria. Energies 2015, 8, 1-30. [CrossRef]

17. Park, E.Y.; Naruse, K.; Kato, T. One-pot bioethanol production from cellulose by co-culture of Acremonium cellulolyticus and Saccharomyces cerevisiae. Biotechnol. Biofuels 2012, 5, 64. [CrossRef] [PubMed]

18. Okamoto, K.; Uchii, A.; Kanawaku, R.; Yanase, H. Bioconversion of xylose, hexoses and biomass to ethanol by a new isolate of the white rot basidiomycete Trametes versicolor. SpringerPlus 2014, 3, 121. [CrossRef]

19. Anasontzis, G.E.; Zerva, A.; Stathopoulou, P.M.; Haralampidis, K.; Diallinas, G.; Karagouni, A.D.; Hatzinikolaou, D.G. Homologous overexpression of xylanase in Fusarium oxysporum increases ethanol productivity during consolidated bioprocessing (CBP) of lignocellulosics. J. Biotechnol. 2011, 152, 16-23. [CrossRef]

20. Maehara, T.; Ichinose, H.; Furukawa, T.; Ogasawara, W.; Takabatake, K.; Kaneko, S. Ethanol production from high cellulose concentration by the basidiomycete fungus Flammulina velutipes. Fungal Biol. 2013, 117, 220-226. [CrossRef]

21. Takano, M.; Hoshino, K. Direct ethanol production from rice straw by coculture with two high-performing fungi. Front. Chem. Sci. Eng. 2012, 6, 139-145. [CrossRef]

22. Lübbehüsen, T.L.; Nielsen, J.; McIntyre, M. Aerobic and anaerobic ethanol production by Mucor circinelloides during submerged growth. Appl. Microbiol. Biotechnol. 2004, 63, 543-548. [CrossRef]

23. Lübbehüsen, T.L.; Nielsen, J.; McIntyre, M. Characterization of the Mucor circinelloides life cycle by on-line image analysis. J. Appl. Microbiol. 2003, 95, 1152-1160. [CrossRef]

24. Karimi, K.; Zamani, A. Mucor indicus: Biology and industrial application perspectives: A review. Biotechnol. Adv. 2013, 31, 466-481. [CrossRef]

25. Inokuma, K.; Takano, M.; Hoshino, K. Direct ethanol production from N-acetylglucosamine and chitin substrates by Mucor species. Biochem. Eng. J. 2013, 72, 24-32. [CrossRef]

26. Millati, R.; Edebo, L.; Taherzadeh, M.J. Performance of Rhizopus, Rhizomucor, and Mucor in ethanol production from glucose, xylose, and wood hydrolyzates. Enzym. Microb. Technol. 2005, 36, 294-300. [CrossRef]

27. Yuan, Z. Microbial Energy Conversion, 1st ed.; De Gruyter: Berlin, Germany, 2018; pp. 154-196.

28. Sampaio, F.C.; Silveira, W.B.d.; Chaves-Alves, V.M.; Passos, F.M.L.; Coelho, J.L.C. Screening of filamentous fungi for production of xylitol from D-xylose. Braz. J. Microbiol. 2003, 34, 325-328. [CrossRef]

29. Chu, L.; Zan, X.; Tang, X.; Zhao, L.; Chen, H.; Chen, Y.Q.; Chen, W.; Song, Y. The role of a xylose isomerase pathway in the conversion of xylose to lipid in Mucor circinelloides. RSC Adv. 2016, 6, 77944-77952. [CrossRef]

30. Ko, J.K.; Um, Y.; Lee, S.-M. Effect of manganese ions on ethanol fermentation by xylose isomerase expressing Saccharomyces cerevisiae under acetic acid stress. Bioresour. Technol. 2016, 222, 422-430. [CrossRef] 
31. Wan, C.; Zhang, M.; Fang, Q.; Xiong, L.; Zhao, X.; Hasunuma, T.; Bai, F.; Kondo, A. The impact of zinc sulfate addition on the dynamic metabolic profiling of Saccharomyces cerevisiae subjected to long term acetic acid stress treatment and identification of key metabolites involved in the antioxidant effect of zinc. Metallomics 2015, 7, 322-332. [CrossRef]

32. Staats, C.C.; Kmetzsch, L.; Schrank, A.; Vainstein, M.H. Fungal zinc metabolism and its connections to virulence. Front. Cell Infect. Microbiol. 2013, 3, 65. [CrossRef]

33. Cuero, R.; Ouellet, T. Metal ions modulate gene expression and accumulation of the mycotoxins aflatoxin and zearalenone. J. Appl. Microbiol. 2005, 98, 598-605. [CrossRef] [PubMed]

34. Zhao, X.Q.; Xue, C.; Ge, X.M.; Yuan, W.J.; Wang, J.Y.; Bai, F.W. Impact of zinc supplementation on the improvement of ethanol tolerance and yield of self-flocculating yeast in continuous ethanol fermentation. J. Biotechnol. 2009, 139, 55-60. [CrossRef]

35. Roy, A.; Kumar, A.; Baruah, D.; Tamuli, R. Calcium signaling is involved in diverse cellular processes in fungi. Mycology 2021, 12, 10-24. [CrossRef] [PubMed]

36. Lee, S.C.; Li, A.; Calo, S.; Inoue, M.; Tonthat, N.K.; Bain, J.M.; Louw, J.; Shinohara, M.L.; Erwig, L.P.; Schumacher, M.A.; et al. Calcineurin orchestrates dimorphic transitions, antifungal drug responses and host-pathogen interactions of the pathogenic mucoralean fungus Mucor circinelloides. Mol. Microbiol. 2015, 97, 844-865. [CrossRef]

37. Rangel-Porras, R.A.; Meza-Carmen, V.; Martinez-Cadena, G.; Torres-Guzmán, J.C.; González-Hernández, G.A.; Arnau, J.; Gutiérrez-Corona, J.F. Molecular analysis of an NAD-dependent alcohol dehydrogenase from the zygomycete Mucor circinelloides. Mol. Genet. Genom. 2005, 274, 354-363. [CrossRef]

38. White, T.J.; Bruns, T.; Lee, S.; Taylor, J. Amplification and direct sequencing of fungal ribosomal RNA genes for phylogenetics. PCR Protoc. A Guide Methods Appl. 1990, 18, 315-322.

39. Abbaszadeh-Mayvan, A.; Ghobadian, B.; Najafi, G.; Yusaf, T. Intensification of continuous biodiesel production from waste cooking oils using shockwave power reactor: Process evaluation and optimization through Response Surface Methodology (RSM). Energies 2018, 11, 2845. [CrossRef]

40. Box, G.E.; Wilson, K.B. On the Experimental Attainment of Optimum Conditions; Springer: New York, NY, USA, 1951; Volume 13, pp. 1-45.

41. Ashwath, N.; Nam, H.; Capareda, S. Maximizing Energy Recovery from Beauty Leaf Tree (Calophyllum inophyllum L.) Oil Seed Press Cake via Pyrolysis. Energies 2021, 14, 2625. [CrossRef]

42. Iwen, P.C.; Sigler, L.; Noel, R.K.; Freifeld, A.G. Mucor circinelloides was identified by molecular methods as a cause of primary cutaneous zygomycosis. J. Clin. Microbiol. 2007, 45, 636-640. [CrossRef]

43. McIntyre, M.; Breum, J.; Arnau, J.; Nielsen, J. Growth physiology and dimorphism of Mucor circinelloides (syn. racemosus) during submerged batch cultivation. Appl. Microbiol. Biotechnol. 2002, 58, 495-502. [CrossRef]

44. Ferreira, J.A.; Lennartsson, P.R.; Edebo, L.; Taherzadeh, M.J. Zygomycetes-based biorefinery: Present status and future prospects Bioresour. Technol. 2013, 135, 523-532. [CrossRef] [PubMed]

45. Fourest, E.; Canal, C.; Roux, J.-C. Improvement of heavy metal biosorption by mycelial dead biomasses (Rhizopus arrhizus, Mucor miehei and Penicillium chrysogenum): $\mathrm{pH}$ control and cationic activation. FEMS Microbiol. Rev. 1994, 14, 325-332. [CrossRef]

46. Moreno, A.D.; Tomás-Pejó, E.; Olsson, L.; Geijer, C. Candida intermedia CBS 141442: A Novel Glucose/Xylose Co-Fermenting Isolate for Lignocellulosic Bioethanol Production. Energies 2020, 13, 5363. [CrossRef]

47. Yang, P.; Zhang, T.; Zhang, Y.; Wang, S.; Liu, Y. Model of R134a Liquid-Vapor Two-Phase Heat Transfer Coefficient for Pulsating Flow Boiling in an Evaporator Using Response Surface Methodology. Energies 2020, 13, 3540. [CrossRef]

48. Ammar, E.M.; Arora, N.; Philippidis, G.P. The Prospects of Agricultural and Food Residue Hydrolysates for Sustainable Production of Algal Products. Energies 2020, 13, 6427. [CrossRef] 